\title{
Eighteen Questions for the Better Understanding of RADS
}

\author{
Stuart M Brooks* \\ Colleges of Public Health \& Medicine, University of South Florida Health Sciences Center, USA
}

*Corresponding author: Stuart M Brooks, Emeritus, Colleges of Public Health \& Medicine, University of South Florida Health Sciences Center, 13201 Bruce B. Downs Boulevard, Tampa, FL 33612, USA, Tel: 7135009459; E-mail: sbrooks2@usf.edu

\begin{abstract}
RADS are typically associated with a solitary inhalation exposure to a very high concentration of an irritant gas, vapor, aerosol or fume. Evolution of asthma-like symptoms and airway hyperresponsiveness are consequences Prompt medical assistance is needed within the first $\mathbf{2 4}$ hours. The manuscript unveils suggested sequences of RADS' pathogenesis. The airway injury causes sloughing off of damaged and dead airway cells. Putatively, escaping intracellular molecules, from dead and damaged cells, enter the extracellular space as damage-associated molecular patterns (DAMPs); they are also known as "alarmins." The molecules promote an inflammatory response and orchestrate cellular repair and tissue healing. Different mediators and regulatory intermediaries, chemokines and cytokines, arachidonic acid products, soluble growth factors, prostaglandins, and matrix components take part in regenerative process. Lung macrophages provide clean-up and repair services: and, they impact airway hyperresponsiveness. Metalloproteinases and extracellular matrix improve the epithelial-tomesenchymal matrix. Airway wall thickening, subepithelial fibrosis, mucus metaplasia, myofibroblast hyperplasia, muscle cells hyperplasia and hypertrophy, and epithelial hypertrophy become features of the airway remodeling response.

Keywords: Reactive Airways Dysfunction Syndrome (RADS); Chest X-ray; Bronchial biopsy; Adult respiratory distress syndrome (ARDS); Acute lung injury (ALI)
\end{abstract}

Received Date: October 24, 2019; Accepted Date: November 02, 2019; Published Date: November 09, 2019

\section{Case Example}

This 39-year-old power plant utility worker experienced a heavy exposure to a 35\% hydrazine solution while transporting a 55-gallon drum containing hydrazine solution at work. The drum accidently overturned and a large quantity of the solution spilled on him. He was pinned down by the drum for about five minutes and could not call for help because of the pressure on his chest. The hydrazine solution flowed onto his face, mouth, neck, chest, arms, abdomen, and urogenital areas. He denied eye exposure, but stated he reflexively swallowed some of the solution. Eventually, a co-worker noted his dilemma and assisted with his removal. He was transported to the First Aid Station where he complained of a "prickly," pins and needles

Citation: Stuart M Brooks, Understanding RADS. J Clin Cases Rep 3(4): 126-138. 
http://www.tridhascholars.org | October-2020

sensation over his face, neck, and anterior chest. A nurse recorded he had a reddish facial rash. About one-half hour later, he reported neck pain, respiratory symptoms with cough and wheezing, nausea, and abdominal cramping. He described wheezing and chest tightness. There was paroxysmal nonproductive coughing and muscle aching. A few hours later, he became dizzy, mentally confused, and confused about time and place. A motor vehicle transported him to a nearby Hospital Emergency Department (ED) for further evaluation and treatment. While in the ED, he complained of worsening respiratory symptoms. Chest X-ray was interpreted as being normal, and without parenchymal infiltrates. He received an injection of corticosteroids but was not admitted to the hospital but discharged from the ED with the diagnosis of "flu-like syndrome." Over the next three weeks, he complained of persistent respiratory symptoms and musculoskeletal weakness. He was bothered by environmental cigarette smoke and aerosol cleaning agents. His Primary Care Physician treated him with repeated courses of tapering doses of prednisone, albuterol inhaler, and an oral theophylline preparation. There was an admission to a hospital for further evaluation. He was breathless on observation on admission. Vital signs were normal except for a pulse rate of 104 beats per minute. Auscultation of his chest disclosed inspiratory and expiratory wheezing. Interpretation of his chest radiograph was "normal." Pulmonary function testing disclosed a moderated degree of airflow limitation. Methacholine challenge was positive with a $\mathrm{PC}_{20}$ of $2.16 \mathrm{mg} / \mathrm{ml}$ methacholine dose. Bronchial biopsy revealed mild lymphocytic inflammation and edematous bronchial mucosa with loosely adherent mucous overlying a partially denuded epithelium.

\section{Introduction}

An exact and full understanding of the various aspects of (RADS) is currently not totally tenable. There remain lingering questions, which require further investigations. RADS are an intrathoracic asthma-like disorder [1]. The Adult Respiratory Distress Syndrome (ARDS) and Acute Lung Injury (ALI) affect more distal lung units (alveoli) causing marked hypoxemia and higher mortality rates. An intrathoracic disorder targeting the smallest sized airways, the bronchioles, leads to bronchiolitis obliterans [2]. Reactive Airways Dysfunction Syndrome (RADS) tend to affect larger sized bronchi rather than bronchioles.

The following discussion presents an assembly of important questions and responses regarding RADS. The contents of this manuscript will address information and topics for gaining a better understanding of the condition.

\section{What is RADS?}

Reactive Airways Dysfunction Syndrome (RADS) is first described in 1985 [1]. Almost all RADS cases are accidental and usually occur without warning [3]. Typical causative agents for RADS are irritating gases, vapors, aerosols and/or fumes including solvent vapors, metallic fumes, and acid mists [4,5]. The foremost clinical characteristics are asthma-like complaints and airway hyperresponsiveness that may persist for a prolonged period. There is need for prompt medical assistance within the first 24 hours after the inhalation exposure [6]. Airflow obstruction may be mild, non-existent, or more persistent [7]. The prognosis is variable. Table 1 presents the diagnostic criteria of RADS [1]. An inhalational exposure first passes through the nose and mouth and contacts the skin and eyes. The eyes, nose, throat (ENT) and/or upper airways sites are not spared. It is biologically unlikely there is absence of accompanying physical signs of injury affecting the eyes, nose, throat (ENT) and/or cornea, conjunctivitis, possibly swelling of the tongue, nasal burning/inflammation, unrelenting rhinitis, redness of the facial skin, and/or inflammation of the larynx [8]. Stethoscope auscultatory findings may reveal wheezing. There is a sound basis for identifying the exposure's chemical makeup. Knowing what constitutes the exposure is imperative. Perusal of the appropriate Material Safety Data Sheets (MSDS) provides valuable information, such as the chemical's actual identity and its physical properties (i.e., vapor pressure, $\mathrm{pH}$ and irritancy). A chemical with a low vapor pressure is less likely to be airborne 
compared to a chemical having a high vapor pressure. Chemicals displaying very high or very low pH values are typically extremely irritating agents. The diagnosis of RADS necessitates recording the onset of asthma-type symptoms within 24 hours after the exposure. A delay of passage of days or weeks between the onset of symptoms and medical care is inconsistent with RADS diagnostic criteria. There is suspicion when the time span is greater than 24 hours.

1. Absence of pre-existing respiratory disorder, asthma symptomatology or a history of asthma in remission and exclusion of conditions that can simulate asthma such as VCD.

2. Onset of asthma symptoms after a single exposure or accident.

3. Exposure is to an irritant vapor, gas, fumes or smoke in very high concentrations.

4. Onset of complaints occurs within minutes to hours and always less than 24 hours after the exposure.

5. Finding of a positive methacholine challenge test $(<8 \mathrm{mg} / \mathrm{ml})$ following the exposure documents nonspecific airway hyperresponsiveness.

6. Possible airflow obstruction on pulmonary function testing.

7. Another pulmonary disorder (such as VCD) to explain the symptoms and findings exclude RADS.

Table 1: Diagnostic Criteria for RADS.

\section{Causes of RADS}

Many types of irritants cause RADS. The condition evolves after an individual inhales a solitary high-level irritant gas, vapor, or fume exposure $[6,8,9]$. Dangerous inhalation events occur in the workplace, the home surroundings, and in various community environmental situations [10]. The originally reported causative agents of RADS were uranium hexafluoride gas, floor sealant, spray paint containing significant concentrations of ammonia, heated acid, 35\% hydrazine, fumigating fog, metal coating remover, and smoke [1]. There may be unanticipated explosions or situations where there is the accidental release of irritant(s) held under pressure. RADS symptoms may ensue following an unforeseen explosion or unexpected environmental chemical release. Performing activities while working within a confined space having a reduced air exchange ventilation rate and/or a space with reduced fresh air make-up are potentially unsafe situations. Elevated emissions of irritating airborne smoke and associated irritant gases accompanying a fire are worrisome [11]. Workers engaged in repairing damaged workplace structures or malfunctioning machines are in danger. Cleaning activities are risky when a worker is not properly equipped, trained, or aware of potential hazardous risks while performing a job [12]. Adverse pulmonary consequences may ensue after an accident involving trains or trucks transporting chemicals. The Bhopal disaster, involving methyl isocyanate, caused serious lung consequences to workers and surrounding residents [13-15]. Intentional inhalational casualties result from chemical warfare attacks during World War I and the Iran-Iraq War. A RADS-like condition affected rescue workers involved with the collapse of New York's World Trade Center on September 11, 2001 [16]. Table 2 lists specific causes of RADS.

\begin{tabular}{|l|l|}
\hline \multicolumn{1}{|c|}{ Exposure } & \multicolumn{1}{|c|}{ Reported Agent or Process } \\
\hline Acids & $\begin{array}{l}\text { Glacial acetic, Sulfuric, Hydrochloric, Hydrofluoric acid, Hydrozoic acid, Hydrobromic acid, } \\
\text { Hydrofluoric acid }\end{array}$ \\
\hline Alkali & Ammonia, Bleach, Sodium hydroxide, Calcium oxide, Sodium hydroxide, World Trade Center dust \\
\hline Gases & $\begin{array}{l}\text { Chlorine, Sulfur dioxide, Mustard, Ozone, Hydrogen sulfide, Phosgene, Nitrogen dioxide; Dinitrogen } \\
\text { tetroxide, Sodium azide gas in automobile airbags }\end{array}$ \\
\hline Spraying & Spraying using paints and coatings \\
\hline Explosion & $\begin{array}{l}\text { Irritant gas, Vapor or fume releases under pressure, Uranium hexafluoride explosion, World Trade Center } \\
\text { disaster }\end{array}$ \\
\hline
\end{tabular}




\begin{tabular}{|l|l|}
\hline Fire/pyrolysis & $\begin{array}{l}\text { Combustion and pyrolysis products of fires, burning paint fumes, pyrolysis products of polyvinylchloride } \\
\text { (PVC) meat wrapping film; smoke inhalation, urea vapors/fumes }\end{array}$ \\
\hline $\begin{array}{l}\text { Confined } \\
\text { spaces }\end{array}$ & $\begin{array}{l}\text { Epichlorhydrin, Acrolein, Floor sealant, Metal coating remover, Biocides, Fumigating aerosol, Cleaning } \\
\text { aerosol sprays, Mixture of drain cleaning agents }\end{array}$ \\
\hline $\begin{array}{l}\text { Environment } \\
\text { \& Workplace }\end{array}$ & $\begin{array}{l}\mathrm{SO}_{2} \text { gas in pyrite mining dust explosion, isocyanates mixed with organic solvent, silicon tetrachloride, } \\
\text { aerosols of metalworking fluid, aluminum smelter workers exposed to pot-room fumes, bleachery } \\
\text { workers with ozone and chlorine dioxide/SO } \mathrm{S}_{2} \text { gassing, anhydrous sodium sulfate release, inorganic salts } \\
\text { used as oxidizing agents in hair bleaches \& hair-coloring preparation, workers exposed to SO }{ }_{2} \text { from } \\
\text { apricot sulfurization, cleaning and disinfecting workers in the food industry, chili pepper pickers, dust } \\
\text { exposure in Norwegian smelters; 2-hydroxyethyl methacrylate and methyl methacrylate in dentists; } \\
\text { synthetic leather workers exposed to organic solvents (toluene, xylene and methyl ethyl ketone); } \\
\text { eucalyptus oil, gases from liquid manure, irritant gas containing chromate at a chrome pellet } \\
\text { manufacturing plant }\end{array}$ \\
\hline
\end{tabular}

Table 2: Causes of RADS.

\section{How Fast Does RADS Develop?}

There is usually a need for prompt medical assistance, within the first 24 hours after the inhalation exposure [6].

\section{Does RADS' Exposure have to be High?}

The definition of RADS requires there be a single high-level irritant gas, vapor, or fume exposure $[1,8]$. The toxicological features and the concentration of the airborne irritant(s) are critical [17]. More than 500 years ago, Paracelsus, the Swiss physician, alchemist, and one of the earliest toxicologists, expounded on the concept of dose-response as he declared in Latin: "sola dosis facit venenum" [18]. In other words: "only the dose makes the poison". RADS transpires when the dose/concentration of the exposure to the hazardous airborne irritant is sufficiently great.

\section{Duration of RADS}

RADS' duration may be short, transient, or prolonged. Approximately $25 \%$ of subjects show a disappearance of bronchial hyperresponsiveness two years after the inhalational accident with a plateau afterwards [19]. In one study, transient respiratory complaints linked to RADS resolved within 12 weeks or less [14]. In other cases, asthma-type symptoms and nonspecific airway hyperresponsiveness persists for years following the inciting irritant exposure [20]. One publication on RADS reports a median duration of symptoms lasting 13 months [5]. The reason for the differences in RADS duration is unknown.

\section{Medical Acknowledgement of RADS}

RADS are now an entity acknowledged by treating physicians and nurse practitioners. Decades ago, allergic occupational asthma is in the forefront of international interest [21-23]. "Experts" are reluctant to fully accept irritants as being capable of causing asthma [24]. Authorities are dubious about the likelihood of nonspecific airway hyperresponsiveness being consequential of a solitary high-level irritant exposure [25]. No published medical report quantifies the intensity of RADS' exposure, mainly because the majorities are accidental in occurrence. There is little documentation that an individual has documented normal bronchial responsiveness prior to the irritant exposure causing RADS. The strict diagnostic criteria for RADS are considered restrictive and circumstantial. Of the latter, practitioners cautiously account a history claiming an absence of preceding symptoms. They must accept there is normal prior lung function, and acknowledge there is no preceding bronchial hyperresponsiveness. Some ask the question as to whether RADS is simply a coincidental incident where the onset of asthma transpires after an irritant exposure. In such a scenario, RADS development is likened to a temporary upper respiratory tract infection preceding a case of asthma. It is not causally proven [24]. Some researchers prefer calling RADS 
http://www.tridhascholars.org | October-2020

"occupational chemical bronchitis." RADS is deemed an "occupational injury" rather than an occupational disease [24]. Some observers question whether RADS is sufficiently unique to be distinguished from the term "inflammatory bronchoconstriction" [26]. Now, in the $21^{\text {st }}$ century, RADS is internationally accepted as a distinct medical entity. The American College of Chest Physicians (ACCP), the American Thoracic Society (ATS), the Canadian Thoracic Society (CTS), the European Thoracic Society (ETS), occupational medical physicians, pulmonologists, and allergists recognize RADS [27].

\section{Legal Acknowledgement of RADS}

RADS cases are compensated. At first, RADS cases are legally rejected because the plaintiffs cannot meet the traditional toxicological exposure-dose criteria for proving causation [28]. The legal unacceptance is eventually reversed as Courts allow a physician's differential diagnosis as proven causation. The United States Court of Appeals for the Seventh Circuit (Illinois) recognizes a different legal proof of causation, referred to as "differential etiology." The United States District Court for the Northern District of Illinois rules that "differential etiology" is a Daubert-compliant proof of RADS. The Court excludes hard and fast "rules" requiring toxicological analysis [28]. Legally, RADS is accepted as a type of sudden onset asthma caused by an exposure to irritant chemicals. It often arises in the work environment and can cause a permanent respiratory injury [28].

\section{A Lower-Level Irritant-Induced Asthma?}

The answer to this question remains controversial. There are numerous pulmonologist who believe it occurs. Possibly, irritantinduced asthma is underreported [29]. Irritant-induced asthma is reported after repeated irritants inhalational exposures taking place over a period of time [30,31]. Other investigators describe similar actualities [32-34)]. Chan-Yeung et al. report on three pulp mill workers who develop "irritant-induced asthma" following multiple episodes of gassing [35]. Tarlo and Broder report several cases of irritant-induced asthma developing after repeated irritant inhalation exposures described as "spills;" they are exposures concentrations exceeding threshold limit values [36]. A retrospective investigation of 86 asthmatic subjects with clinical features of irritant-induced asthma is undertaken [37]. A collection of subjects experience brief repeated irritant exposures transpiring over weeks or months. In these cases, the initiation of asthma takes longer to evolve. The group with this clinical scenario is referred to as "not-so-sudden" irritant-induced asthma. Eighty-eight percent of individuals with notso-sudden irritant-induced asthma display a statistically significant history suggestive of an atopic disposition. An allergic diathesis may be important in these types of cases. Some of the subjects in this group experience childhood asthma. Their childhood asthmatic condition resolves and remains quiescent for at least one year before the exacerbating irritant exposure occurs. Preexisting atopy and/or preexisting asthma appear as contributors to the pathogenesis of some not-so-sudden irritantinduced asthma cases. This contention is challenged by others [38]. There are also cases depicted as "low dose" RADS where asthma onset is after an irritant exposure that is less intense or acute in nature [39].

\section{Allergy in Relation to RADS?}

The answer to the question is maybe but not yet proven. RADS are considered a type of non-allergic airway disease. Asthma is divided into two distinct variants: (1) the extrinsic, allergic asthma variant occurs in the context of sensitization toward environmental allergens and is accompanied by elevated serum IgE levels; and, (2) a non-allergic/intrinsic asthma variant, with no detectable sensitization; it shows low serum IgE levels [40]. Non-allergic asthma is considered to be a distinct pathogenetic variant [41]. The most important inducers of the increase serum IgE in patients with allergic asthma are the cytokines IL-4 and IL-13 [42]. Their role in RADS is unknown. The inflammatory processes in both allergic and nonallergic asthma types show similarities but also differences [40]. A qualitative difference between the mucosal tissue of patients with 
http://www.tridhascholars.org | October-2020

allergic and nonallergic asthma is the concentration of the chemokine RANTES, which are formed by certain macrophage subtypes [41]. The amount of RANTES in the bronchoalveolar lavage fluid of patients with nonallergic asthma is higher than in patients with allergic asthma [40]. It seems that allergy is not a direct mechanism for RADS, but perhaps, may represent a predisposition for enhanced irritant responsiveness [37] An asymptomatic individual with roots in childhood asthma may have their asthma exacerbated by accidental repeated irritant exposures [43,44]. Many young individuals with allergic childhood asthma enter a complete remission or display a reduction in asthma symptoms between the ages of 10 and 20 years [45]. Never the less, while the severity of asthma symptoms fluctuates with time, the inherited tendency towards future respiratory symptoms never disappears [46,47]. Asymptomatic asthmatic subjects can still demonstrate substantial air flow limitation and show increases in bronchial hyperresponsiveness. The presence of airway hyperresponsiveness (AHR)) is a cardinal feature of RADS. The relationship between AHR and inflammation of the airways is well established [48]. Interleukin-13 may play a unique role in the development of AHR in RADS [49]. ADAM33 has been reported to be susceptibility gene linked to AHR [50].

\section{Mimic of RADS and Asthma}

Vocal Cord Dysfunction (VCD) clinically imitates both RADS and bronchial asthma [51-53]. The Irritable Larynx Syndrome causes laryngeal hyperresponsiveness [54]. Vocal cords exist in the larynx, the throat, an extrathoracic site [55]. RADS location is in an intrathoracic site, the bronchial tree. Purportedly, a single odorous irritant exposure causes VCD [56]. A publication asserts that irritants cause VCD mimicking RADS [57]. The assertion is doubted by others [58].

\section{Odors and VCD}

Odorants can trigger VCD [59]. Suggestive tip-offs for suspecting odorant-related VCD instead of RADS are: (1) hoarseness and/or voice change; (2) heightened sensitivity to numerous odorants and scents; and, (3) unresponsiveness to aggressive asthma/RADS pulmonary treatment regimens [60,61]. There may be excessive worry, apprehension, repeated Emergency Department visits, and/or hospitalizations. Unlike asthmatics, VCD patients rarely awaken from sleep due to acute attacks. There may be constricting throat complaints. Patients with VCD (asserted as RADS) typically receive treatment with asthmatype medications such as aerosol bronchodilators and/or oral or parenteral corticosteroids. Be cognizant of VCD by observing for evidence of posterior nasal drainage and/or gastro-esophagus reflux disease (GERD), supposed contributors to vocal cord hyper reactivity. The physical examination is stereotypically "normal" between acute VCD attacks. The chest x-rays shows no lung abnormalities or hyperinflation. Measurement of residual volume is not increased, a finding typical of an asthmatic patient. Spirometry clinches the diagnosis during an acute VCD interlude. Imperatively, the spirometer used for testing must provide a visual flow-volume (FV) tracing for uncovering VCD [62]. Vocal cord closure may occur during both phases of respiration [63]. Change in the inspiratory loop of the FV curve is pathognomonic of VCD. The inspiratory loop of the flowvolume curve will be truncated or show flattening [64]. According to the American Thoracic Society, at least three spirometric tracings are necessary, with two of the three loops showing consistency [62]. Patients with pure VCD do not have a bronchodilator response and in many instances seem to have difficulty performing consistent spirometric tracings. Some clinicians consider endoscopic examination with direct visualization of the vocal folds via flexible, trans nasal fiber-optic laryngoscopy during an acute attack as the gold standard for diagnosis of VCD [51,55]. There is observation of adduction (closure) of the anterior two-thirds of the vocal cords with posterior chinking that creates a diamond shape [56]. The endoscopic examination of a patient with VCD tends to be normal when the patient is symptom-free. Vocal cord visualization via endoscopy is accomplished with the patient executing sniffing, phonating, rapid panting, and repetitive deep breathing 
http://www.tridhascholars.org | October-2020

maneuvers [63,65]. Provocation testing utilizes administration of aerosolized methacholine or inhaled mannitol powder, strenuous exercise, and/or breathing in refrigerated cold air. Specialized centers test for VCD induction by inhaling odorants/irritants, such as perfume or cleaning agents containing chlorine or ammonia [66].

\section{VCD Diagnosed and Treatment}

Symptoms improve with interventional speech therapy in contrast to the treatment by a pulmonologist [56,64,67]. Diagnostic videostroboscopy involves insertion of a steel scope containing a tiny camera and strobe light placed inside the patient's mouth. The camera is angled to allow a clear view of the patient's interior throat enabling a videotape of vocal cord movement and vibration in slow motion. The camera projects a moving image of the vocal cords, frame by frame, onto the television monitor, instantly retrievable as a video recording or as a still photo.

\section{Pathology of RADS?}

The originally reported cases of RADS identify mononuclear cell inflammation, denuded epithelium, and edematous mucosa days to weeks after the exposure [1]. Mucosal squamous cell metaplasia, thickening of the basement membrane and reticulum, and collagen-associated bronchial wall fibrosis are other pathological findings $[67,68]$. In a human investigation, bronchial biopsies are obtained at three and 15 days after an accidental workplace inhalational of chlorine gas; later biopsies are taken at three and five months [69]. The earliest bronchial biopsy depicts mucosal cellular denudation with sloughing of epithelial cells and infiltration of a submucosal fibrinohemorrhagic exudate [69]. Cellular regeneration involves mucosal basal and parabasal cells proliferation and deposition of collagen. Another study involves inhalation of sodium hypochlorite and hydrochloric acid [67]. Biopsy samples, several months after the exposure, display persistence of cellular destruction, lymphocytic inflammation, and subepithelial fibrosis without thickening of the basement membrane. Sprague-Dawley rats sustain a single exposure to 1,500 parts per million of chlorine gas for 5 minutes, mirroring a human RADS scenario [70,71]. At 24 hours after the exposure, the rat's airway biopsy exhibits a severe injury to the bronchial mucosal with sloughing of damaged epithelial cells and their cellular detachment from the basement membrane. Bronchoalveolar lavage fluid identifies acute neutrophilic inflammation. Signs of epithelial regeneration show epithelial stratification by the third day after the exposure. Cellular regeneration changes persist for seven days. Increasing numbers of mucus-secreting cells reach maximal capacity by 14 days. Regeneration changes are observed up to 30 days after exposure. Pathological abnormalities clear approximately 90 days after the exposure.

\section{Is There an Explanation for Rads Pathogenesis?}

RADS employs mechanisms of innate immunity rather than adapted allergy/immunologic immunity following a nonmicrobiological inhalation exposure. An inhaled irritant exposure severely damages airways' epithelial cells and mucosal surfaces leading to the exodus of intracellular constituents into the extracellular space where they prompt an innate repair processes. Numerous bioactive molecules contribute to cellular and tissue repair processes (72-81). Soluble growth factors, cytokines, chemokines, interleukins, prostaglandins discharges, matrix constituents, fibroblasts actions, and endothelial cells endeavors work in concert for accomplishing airways repair (82-84). Lung macrophages migrate to assist in the repair and clean-up processes (85-89). It is not evident whether airway wall and basement membrane thickening, subepithelial fibrosis, goblet cell and submucosal gland enlargement, myofibroblast hyperplasia, increased smooth muscle mass, decreased cartilage integrity, and increased airway vascularity are characteristic for RADS as in typical bronchial asthma (90-91). 


\section{Is RADS a Unique Phenotype?}

The answer is unknown. Phenotype differentiation has been applied to subtypes of asthma but not to RADS [92-95]. Possibly, repeated exposure-type irritant-induced asthma (e.g., not-so-sudden) exemplifies a distinct asthma phenotype.

\section{How is RADS Treated?}

The treatment of RADS is similar to the treatment afforded patients suffering from an acute inhalational injury. Aerosolized bronchodilators are helpful for treating bronchoconstriction (as measured by spirometry) or bronchospasm (as determined by auscultation finding of wheezing). The beneficial effect of parenteral steroids has been shown in an animal model of RADS in which dexamethasone was administered immediately before chlorine inhalation [96]. No human study shows oral corticosteroid efficacy in the treatment of RADS after the exposure. Inhaled steroids may reduce the degree of airway hyperresponsiveness [69].

\section{Discussion}

The American College of Chest Physicians (ACCP), the American Thoracic Society (ATS), the Canadian Thoracic Society (CTS), the European Thoracic Society (ETS), occupational medical physicians, pulmonologists, and allergists recognize the role of irritancy in causing acute airway symptom and disorders such as RADS [3]. Newer information delving into molecular information learned about injury in bronchial asthma permits a better understanding of RADS.

\section{Conclusion}

Reactive Airways Dysfunction Syndrome (RADS) is an abrupt-onset asthmatic disorder of a non-allergy origin after inhalation of a single high-level irritant exposure. The inhaled exposure assaults the airways' epithelial cells and mucosal surface, a first line of airway defense. Implementation of innate immunity permits the airways to deal with nonmicrobiological constituents arising after a massive irritant inhalation exposure. The treatment of RADS is similar to the treatment afforded patients suffering from an acute inhalational injury.

\section{Conflict of Interest}

I certify that I (Stuart M. Brooks, MD) am the guarantor and the only corresponding author. I hold no potential conflicts of interest; no sources of funding and support; no information on statistical analyses; correct name/participation/degree/ institution of the only author. I also certify that I did not accept compensation for inclusion of any of the statements contained in the manuscript.

\section{References}

1. Brooks SM, Weiss MA, Bernstein IL (1985) Reactive airways dysfunction syndrome (RADS): Persistent asthma syndrome after high level irritant exposures. Chest 88(3): 376-384.

2. King JT (1993) Overview of bronchiolitis. Clinics in Chest Medicine 14(4): 607-610.

3. Kern DG (1991) Outbreak of the reactive airways dysfunction syndrome after a spill of glacial acetic acid1-4. The American Review of Respiratory Disease Returns 144: 1058-1064.

4. McDonald JC, Chen Y, Zekveld C, et al. (2005) Incidence by occupation and industry of acute work related respiratory diseases in the UK, 1992-2001. Occupational and Environmental Medicine 62(12): 836-842. 
5. Shakeri MS, Dick FD, Ayres JG (2008) Which agents cause reactive airways dysfunction syndrome (RADS)? A systematic review. Occupational Medicine (London) 58(3): 205-211.

6. Lemière C, Boulet LP, Cartier A (2016) Reactive airways dysfunction syndrome and irritant induced asthma.

7. Kowitz TA, Reba RC, Parker RT, et al. (1967) Effects of chlorine gas upon respiratory function. Archives of Environmental Health: An International Journal 14(4): 545-558.

8. Meggs WJ (1994) RADS and RUDS the toxic induction of asthma and rhinitis. Journal of Toxicology: Clinical Toxicology 32(5): 487-501.

9. Kopferschmitt-Kubler MC, Ameille J, Popin E, et al. (2002) Occupational asthma in France: A 1-yr report of the observatoire National de Asthmes Professionnels project. European Respiratory Journal 19(1): 84-89.

10. Nemery B (2006) Inhalation injury, chemical. In: Nemery B, editor. Occupational Diseases London: Elsevier Ltd: 208216.

11. Stenton SC, Kelly CA, Walters EH, et al. (1988) Induction of bronchial hyperresponsiveness following smoke inhalation injury. British Journal of Diseases of the Chest 82: 436-438.

12. Valent F, McGwin Jr G, Bovenzi M, et al. (2002) Fatal work-related inhalation of harmful substances in the United States. Chest 121(3): 969-975.

13. Broughton E (2005) The Bhopal disaster and its aftermath: A review. Environmental Health 4(1): 1-6.

14. Nemery B (1996) Late consequences of accidental exposure to inhaled irritants: RADS and the Bhopal disaster. European Respiratory Journal 9(10): 1973-1976.

15. Sriramachari S (2004) The Bhopal gas tragedy: An environmental disaster. Current Science 86(7): 905-920.

16. Banauch GI, Alleyne D, Sanchez R, et al. (2003) Persistent hyperreactivity and reactive airway dysfunction in firefighters at the World Trade Center. American Journal of Respiratory and Critical Care Medicine 168(1): 54-62.

17. Alarie Y (1981) Dose-response analysis in animal studies: Prediction of human responses. Environmental Health Perspectives 42: 9-13.

18. Grandjean P (2016) Paracelsus revisited: The dose concept in a complex world. Basic \& Clinical Pharmacology \& Toxicology 119(2): 126-132.

19. Malo JL, Cartier A, Boulet LP, et al. (1994) Bronchial hyperresponsiveness can improve while spirometry plateaus two to three years after repeated exposure to chlorine causing respiratory symptoms. American Journal of Respiratory and Critical Care Medicine 150(4): 1142-1145.

20. Malo JL, L'Archeveque J, Castellanos L, et al. (2009) Long-term outcomes of acute irritant-induced asthma. American Journal of Respiratory and Critical Care Medicine 179(10): 923-928.

21. Franz T, McMurrain KD, Brooks S, et al. (1971) Clinical, immunologic, and physiologic observations in factory workers exposed to B. subtilis enzyme dust. Journal of Allergy and Clinical Immunology 47(3): 170-180.

22. Chan-Yeung M, Barton GM, MaClean L, et al. (1973) Occupational asthma and rhinitis due to western red cedar (Thuja plicata). American Review of Respiratory Disease 108(5): 1094-1102.

23. Brooks SM (2010) Bronchial asthma of occupational origin. Scandinavian Journal of Work, Environment \& Health 3(2): 53-72.

24. Kennedy SM (1992) Acquired airway hyperresponsiveness from nonimmunogenic irritant exposure. Occupational Medicine (Philadelphia) 7(2): 287-300.

25. Bardana Jr. EJ (1999) Reactive airways dysfunction syndrome (RADS): Fact or fantasy?. Allergy 54: 33-35. 
http://www.tridhascholars.org | October-2020

26. Barnes PJ (1991) Neurogenic inflammation in airways. International Archives of Allergy and Immunology 94(1-4): 303309.

27. Kern DG, Sherman CB (1994) What is this thing called RADS?. Chest 106(6): 1643-1645.

28. Axelrod DA, Cohen RA (2013) Toxic respiratory exposure cases and daubert: Application of differential etiology and the development of cases involving reactive airways dysfunction syndrome (RADS). Trial Journal Archives - Illinois Trial Lawyers Association 15: 1-15.

29. Baur X, Bakehe P, Vellguth H (2012) Bronchial asthma and COPD due to irritants in the workplace-an evidence-based approach. Journal of Occupational Medicine and Toxicology 7(1): 1-31.

30. Tarlo SM (2003) Workplace irritant exposures: do they produce true occupational asthma?. Annals of Allergy, Asthma \& Immunology 90(5): 19-23.

31. Balmes JR (2002) Occupational airways diseases from chronic low-level exposures to irritants. Clinics in Chest Medicine 23(4): 727-735.

32. Malo JL (1998) Irritant-induced asthma and reactive airways dysfunction syndrome. Canadian Respiratory Journal 5(1): 66-67.

33. Labrecque M (2012) Irritant-induced asthma. Current Opinion in Allergy and Clinical Immunology 12(2): 140-144.

34. Quirce S, Gala G, Pérez-Camo I, et al. (2000) Irritant-induced asthma: clinical and functional aspects. Journal of Asthma 37(3): 267-274.

35. Chang-Yeung M, Lam S, Kennedy SM, et al. (1994) Persistent asthma after repeated exposure to high concentrations of gases in pulpmills. American Journal of Respiratory and Critical Care Medicine 149(6): 1676-1680.

36. Tarlo SM, Broder I (1989) Irritant-induced occupational asthma. Chest 96(2): 297-300.

37. Brooks SM, Hammad Y, Richards I, et al. (1998) The spectrum of irritant-induced asthma: sudden and not-so-sudden onset and the role of allergy. Chest 113(1): 42-49.

38. Tarlo SM (2010) Irritant-induced asthma PCCSU 24 (Lesson 22): 1-6.

39. Kipen HM, Blume R, Hutt D (1994) Asthma experience in an occupational and environmental medicine clinic. Lowdose reactive airways dysfunction syndrome. Journal of Occupational Medicine: Official Publication of the Industrial Medical Association 36(10): 1133-1137.

40. Novak N, Bieber T (2003) Allergic and nonallergic forms of atopic diseases. Journal of Allergy and Clinical Immunology 112(2): 252-262.

41. Pillai P, Corrigan CJ, Ying S (2011) Airway epithelium in atopic and nonatopic asthma: Similarities and differences. ISRN Allergy, 2011: 1-7.

42. Gour N, Wills-Karp M (2015) IL-4 and IL-13 signaling in allergic airway disease. Cytokine 75(1): 68-78.

43. Bradding P, Green RH (2010) Subclinical phenotypes of asthma. Current Opinion in Allergy and Clinical Immunology 10(1): 54-59.

44. Sessions CK (2009) Asthma, active component, US Armed forces, 1999-2008. In: Center AFHS, editor. Medical Surveillance Monthly Report (MSMR) - A publication of the Armed Forces Health Surveillance Center. Silver Spring, MD Armed Forces Health Surveillance Center (AFHSC): 5-9.

45. Panhuysen CI, Vonk JM, Koëter GH, et al. (1997) Adult patients may outgrow their asthma: a 25-year follow-up study. American Journal of Respiratory and Critical Care Medicine 155(4): 1267-1272. 
http://www.tridhascholars.org | October-2020

46. Riiser A, Hovland V, Carlsen KH, et al. (2012) Does bronchial hyperresponsiveness in childhood predict active asthma in adolescence?. American Journal of Respiratory and Critical Care Medicine 186(6): 493-500.

47. Sears MR (2012) Predicting new and persistent asthma. American Journal of Respiratory and Critical Care Medicine 186: 469-479.

48. Meurs H, Gosens R, Zaagsma J (2008) Airway hyperresponsiveness in asthma: Lessons from in vitro model systems and animal models. European Respiratory Journal 32(2): 487-502.

49. Mattes J, Yang M, Siqueira A, et al. (2001) IL-13 induces airways hyperreactivity independently of the IL-4R $\alpha$ chain in the allergic lung. The Journal of Immunology 167(3): 1683-1692.

50. Holgate ST, Davies DE, Murphy G, et al. (2003) ADAM 33: just another asthma gene or a breakthrough in understanding the origins of bronchial hyperresponsiveness?. Thorax 58: 466-469.

51. Kenn K, Hess MM (2008) Vocal cord dysfunction: an important differential diagnosis of bronchial asthma. Deutsches Ärzteblatt International 105(41): 699-700.

52. Brugman SM, Simons SM (1998) Vocal cord dysfunction: Don't mistake it for asthma. The Physician and Sports Medicine 26(5): 63-85.

53. Daley CP, Ruane LE, Leong P, et al. (2019) Vocal cord dysfunction in patients hospitalised with symptoms of acute asthma exacerbation. American Journal of Respiratory and Critical Care Medicine 200: 782-785.

54. Morrison M, Rammage L, Emami AJ (1999) The irritable larynx syndrome. Journal of Voice 13(3): 447-455.

55. Dunn NM, Katial RK, Hoyte FC (2015) Vocal cord dysfunction: A review. Asthma Research and Practice 1(1): 1-9.

56. Huggins JT, Kaplan A, Martin-Harris B, et al. (2004) Eucalyptus as a specific irritant causing vocal cord dysfunction. Annals of Allergy, Asthma \& Immunology 93(3): 299-303.

57. Perkner JJ, Fennelly KP, Balkissoon R, et al. (1998) Irritant-associated vocal cord dysfunction. Journal of Occupational and Environmental Medicine 40(2): 136-143.

58. Bahrainwala AH, Simon MR (2001) Wheezing and vocal cord dysfunction mimicking asthma. Current Opinion in Pulmonary Medicine 7(1): 8-13.

59. Brooks SM (2017) Vocal cord dysfunction after an inhalation exposure. Journal of Allergy \& Therapy 8: 1-8.

60. Dalton P (2003) Upper airway irritation, odor perception and health risk due to airborne chemicals. Toxicology Letters 140-141: 239-248.

61. Brooks SM (2018) Inhalation exposures and vocal cord dysfunction Jacobs Journal of Pulmonology 4(3): 1-16.

62. Culver BH, Graham BL, Coates AL, et al. (2017) Recommendations for a standardized pulmonary function report. An official American Thoracic Society technical statement. American Journal of Respiratory and Critical Care Medicine 196(11): 1463-1472.

63. Newman KB, Mason $3^{\text {rd }}$ UG, Schmaling KB (1995) Clinical features of vocal cord dysfunction. American Journal of Respiratory and Critical Care Medicine 152(4): 1382-1386.

64. Vlahakis NE, Patel AM, Maragos NE, ET AL. (2002) Diagnosis of vocal cord dysfunction: the utility of spirometry and plethysmography. Chest 122(6): 2246-2249.

65. Morris MJ, Christopher KL (2010) Diagnostic criteria for the classification of vocal cord dysfunction. Chest 138(5): 1213-1223.

66. Kenn K, Balkissoon R (2011) Vocal cord dysfunction: what do we know?. European Respiratory Journal 37(1): 194200. 
http://www.tridhascholars.org | October-2020

67. Deschamps D, Soler P, Rosenberg N, et al. (1994) Persistent asthma after inhalation of a mixture of sodium hypochlorite and hydrochloric acid. Chest 105(6): 1895-1896.

68. Gautrin D, Bernstein IL, Brooks SM, et al. (2006) Reactive airways dysfunction syndrome, or irritant induced asthma. In: Bernstein IL, Chan Yeung M, Luc-Malo J, DB (Eds.) Asthma in the workplace.

69. Lemiere C, Malo JL, Boutet M (1997) Reactive airways dysfunction syndrome due to chlorine: sequential bronchial biopsies and functional assessment. European Respiratory Journal 10(1): 241-244.

70. Demnati R, Fraser R, Ghezzo H, et al. (1998) Time-course of functional and pathological changes after a single high acute inhalation of chlorine in rats. European Respiratory Journal 11(4): 922-928.

71. Demnati R, Fraser R, Plaa G, et al. (1995) Histopathological effects of acute exposure to chlorine gas on Sprague-Dawley rat lungs. Journal of Environmental Pathology, Toxicology and Oncology: Official Organ of the International Society for Environmental Toxicology and Cancer 14(1): 15-19.

72. Parker D, Prince A (2011) Innate immunity in the respiratory epithelium. American Journal of Respiratory Cell and Molecular Biology 45(2): 189-201.

73. Laitinen LA, Heino M, Laitinen A, et al. (1985) Damage of the airway epithelium and bronchial reactivity in patients with asthma. American Review of Respiratory Disease 131(4); 599-606.

74. Miller K, Chang A (2003) Acute inhalation injury. Emergency medicine clinics of North America 21(2): 533-557.

75. Weathington N, O'Brien ME, Radder JE, et al. (2019) Bronchoalveolar lavage cell gene expression in severe asthma reveals mechanisms of severe disease and influences of medications. American Journal of Respiratory and Critical Care Medicine 200: 837-856.

76. Zemans RL, Henson PM, Henson JE, et al. (2015) Conceptual approaches to lung injury and repair. Annals of the American Thoracic Society 12(Supplement 1): S9-S15.

77. Knight DA, Holgate ST (2003) The airway epithelium: Structural and functional properties in health and disease. Respirology 8(4): 432-446.

78. Howarth PH, Redington AE, Springall DR, et al. (19950 Epithelially derived endothelin and nitric oxide in asthma. International Archives of Allergy and Immunology 107(1-3): 228-230.

79. Lazaar AL, Panettieri Jr. RA (2005) Airway smooth muscle: a modulator of airway remodeling in asthma. Journal of Allergy and Clinical Immunology 116(3): 488-495.

80. Doeing DC, Solway J (2013) Airway smooth muscle in the pathophysiology and treatment of asthma. Journal of Applied Physiology 114(7): 834-843.

81. Barnes PJ, Chung KF, Page CP (1998) Inflammatory mediators of asthma: An update. Pharmacological Reviews 50(4): 515-596.

82. Crosby LM, Waters CM (2010) Epithelial repair mechanisms in the lung. American Journal of Physiology-Lung Cellular and Molecular Physiology 298(6): L715-L731.

83. Crystal RG, Randell SH, Engelhardt JF, et al. (2008) Airway epithelial cells: Current concepts and challenges. Proceedings of the American Thoracic Society 5(7): 772-777.

84. Fujishima S (2011) Epithelial cell restoration and regeneration in inflammatory lung diseases. Inflammation and Regeneration 31(3): 290-295.

85. Bentley AM, Durham SR, Kay AB (1994) Comparison of the immunopathology of extrinsic, intrinsic and occupational asthma. Journal of Investigational Allergology \& Clinical Immunology 4(5): 222-232. 
86. Byrne AJ, Mathie SA, Gregory LG, et al. (2015) Pulmonary macrophages: Key players in the innate defence of the airways. Thorax 70(12): 1189-1196.

87. Lambrecht BN (2006) Alveolar macrophage in the driver's seat. Immunity 24(4): 366-368.

88. Song C, Luo L, Lei Z, et al. (2008) IL-17-producing alveolar macrophages mediate allergic lung inflammation related to asthma. The Journal of Immunology 181(9): 6117-6124.

89. Brightling CE, Symon FA, Birring SS, et al. (2003) Comparison of airway immunopathology of eosinophilic bronchitis and asthma. Thorax 58(6): 528-532.

90. Holgate ST, Davies DE, Lackie PM, et al. (2000) Epithelial-mesenchymal interactions in the pathogenesis of asthma. Journal of Allergy and Clinical Immunology 105(2): 193-204.

91. Elias JA, Zhu Z, Chupp G, et al. (1999) Airway remodeling in asthma. The Journal of Clinical Investigation 104(8): 1001-1006.

92. Bel EH (2004) Clinical phenotypes of asthma. Current Opinion in Pulmonary Medicine 10(1): 44-50.

93. Wenzel SE (2004) Phenotypes in asthma. American Journal of Respiratory and Critical Care Medicine 170: 579-582.

94. Haldar P, Pavord ID, Shaw DE, et al. (2008) Cluster analysis and clinical asthma phenotypes. American Journal of Respiratory and Critical Care Medicine 178(3): 218-224.

95. Kiley J, Smith R, Noel P (2007) Asthma phenotypes. Current Opinion in Pulmonary Medicine 13(1): 19-23.

96. Demnati R, Fraser R, Ghezzo H, et al. (1998) Time-course of functional and pathological changes after a single high acute inhalation of chlorine in rats. European Respiratory Journal 11(4): 922-928. 